\title{
Effects of utilizing treated and untreated corncobs and cassava peel-based diets on carcass and meat performance of West African dwarf goats
}

${ }^{* 1}$ Apata, E. S., ${ }^{1}$ Eniolorunda, O. O., ${ }^{1}$ Olugbemi, E. S. and ${ }^{2}$ Adedeji, O. Y.

${ }^{I}$ Meat Science Laboratory; Olabisi Onabanjo University, P.M.B 0012 Ayetoro, Ogun

State, Nigeria

${ }^{2}$ Department of Animal Production Technology, Federal College of Animal Health

and Production Technology, Moor Plantation, Ibadan, Oyo State, Nigeria

*Corresponding author: ebunoluapata2008@yahoo.com;

Abstract

$08108177177 ; 08058871714$

A study was conducted to investigate the effect of utilizing treated and untreated corncobs and cassava peels-based concentrate diets on carcass and meat performance of West African Dwarf (WAD) buck goats. Sixteen WAD buck goats of ages between 9 and 10 months, balanced for weight were randomly assigned to four diet treatments with four goats per treatment diets of $T 1=$ untreated cassava peels $T 2=$ Treated corncobs, $T 3=$ Treated cassava peels and T4 = untreated corncobs for 91 days. At the end of the feeding trial, three goats were randomly selected from each treatment and slaughtered. Data were collected on fasted, bled, clean carcasses' weights, lengths, chilled weights, chilling losses, chilling loss weights and dressing percentages as well as external and internal offals, while data on physical, (cooking loss, cooking yield, thermal shortening, cold loss, cold shortening and water holding capacity) proximate (moisture, crude protein, ether extract (fat), ash and nitrogen free extract) and organoleptic (colour, flavour, tenderness, juiciness, texture and overall acceptability) properties of meat were taken in a completely randomized experiment. Data were statistically analysed and significant means were separated at $p=0.05$. The results of the chemical composition of the experimental diets showed significant differences. Clean carcasses' lengths and chilled weights were higher in T3 than in other treatments, while bled carcasses' weights and chilling losses were lower $(p<0.05)$ in the same T3 than in others. Bled carcasses' weights, chilling losses and percentage chilling losses were higher in T1 and $T 4$ respectively. All the external and internal offals were higher in T3 followed by T2 and least $(p<0.05)$ in T4, but cooking yield and water holding capacity were higher in T3 while thermal shortening, cold loss and shortening were lower. Moisture, crude protein, ether extract (fat) and ash except nitrogen free extract were higher in T3 followed by T1, T2 and least $(p<0.05)$ in T4. Meat from T3 had higher colour, flavour, tenderness, juiciness, texture and overall acceptability followed by meat from T2 and least in T4. All the variables measured except nitrogen free extract were higher in T3. It can be concluded based that diet T3 was the best due to higher effect on the carcasses and meats of experimental goats. Therefore, diet T3 is highly recommended for farmers followed by diet T2.

Keywords: Carcass, cassava peels, corncobs, meat performance, WAD goats.

\section{Introduction}

Goat is one of the oldest domesticated animals and has been used for meat, milk, and mohair and skins production over the years. The world population of goats was estimated at 924 million (FAOSTAT, 2005) with $96 \%$ of this figure being kept in developing countries. Goats have been contributing immensely to the global meat and milk production to the time of 285.7 and 671.3 million tonnes respectively (FAOSTAT, 2007). The breeds of goats in Nigeria and other West African Countries are largely indigenous in West African 


\section{Effects of utilizing treated and untreated corncobs and cassava peel-based diets}

Dwarf(WAD), Sahel or Desert and the RedSokoto or Maradi goats of which distribution shows that WAD is common in the Southern, while the Sahel and RedSokoto are native of the Northern Nigeria (Apata, 2011).

The body weight of goats that are traditionally sold for slaughter varies from 25 to $30 \mathrm{~kg}$, resulting in average carcass weight of 12 to $13 \mathrm{~kg}$, usually from animals over a year old (Matto et al., 2006). Goat Production in Nigeria comprises largely of traditional rearing system which is characterized by irregular and inadequate feeding that necessitates research into nonconventional feedstuffs that are cheaper and not in high demand by humans can be exploited for livestock particularly for goatproduction in Nigeria (Apata, 2011). Cassava peels represent $5.15 \%$ of the root, which can be used as roughages and energy feed in ruminants diets (Amaefule and Ibeawychi, 2003) with the use of either sun drying, ensiling or fermentation to reduce the cyanide content are a valuable feed which significantly increase ruminants performance due to high digestibility (Abdu et al., 2013). Also, Corncobs had been reported to be very high in chemical composition with or without enzyme supplementation and improve digestibility coefficient in ruminants (Bolanle and Saliu, 2012).

Therefore, Corncobs and Cassava peels which probably constitute nuisance in the environment can be successfully recycled into value added substrate for ruminant feed (Abores et al., 2006). The aim of this study was to untreated Corncobs and cassava peels-based diets on carcass and meet performance of West African dwarf goats.

\section{Materials and methods \\ Studyarea}

The feeding trial was conducted at the Small Ruminants Experimental Unit of the College of Agricultural Sciences Teaching and Research Farm, Olabisi Onabanjo University, Ayetoro Campus, Ogun State, Nigeria. The area falls within latitude $7^{\circ} 15$ North and longitude $3^{\circ} 3^{\prime}$ East in the derived Savannah Zone of Ogun State with annual rainfall of $1900 \mathrm{~mm}$, maximum temperature between 29 and $34^{\circ} \mathrm{C}$ and relative humidity of $81 \%$ (Onakomaya et al 1992).

\section{Experimental diets}

Corncobs (CCB) were obtained from local farms in Ayetoro and were dried to $15 \%$ moisture and packed into an air tight container for 20days to attain fermentation sun dried and milled with a $6 \mathrm{~mm}$ blade bagged and stored. Also, Cassava Peel (CPL) was collected locally from farmers in Ayetoro, $8 \mathrm{~cm}$ dried to $10 \%$ moisture, bagged and stoned. Glyciridia sepium leaves were from trees in the surroundings of the farm, sun dried and to $10 \%$ moisture, bagged and stoned; while Brewers' dry grains, wheat offals and molasses were purchased from industries. Polyenzyme (Maxigrain $\left.{ }^{\circledR}\right)$ was incorporated into the diet at $0.13 \%$. Four treatment diets were formulated viz; $\mathrm{T} 1=50 \% \mathrm{CPL}$ without enzyme, $\mathrm{T} 2=50 \% \mathrm{CCB}$ with enzyme, $\mathrm{T} 3=$ $50 \%$ CPL with enzyme, $\mathrm{T} 4=\mathrm{CCB}$ without enzyme. Experimental Animals, Feeding and Management Sixteen West African Dwarf bucks were procured from Igbogila Village around Ayetoro age about 8-10 months old and with body weight of between 6.40 and $9.70 \mathrm{~kg}$ were used for this study. The goats were acclimatized for 21 days at which period they were dipped in Diazintol solution against ecto-parasites, dewormed with Ivomec against internal parasites and were vaccinated against Pestes des Petit Ruminant (PPR) as well as injected with Oxytetracycline (LA) antibiotic and Vitamin B-Complex intramuscularly at the dosage of $1 \mathrm{ml} / 10 \mathrm{~kg}$ live weight of the animals in order to enhance their resistance of infections and stress (Ikihimioya et al, 2007). The goats were randomly allocated into the four 


\section{Apata, Eniolorunda, Olugbemi and Adedeji}

dietary treatments in a completely randomized design. Each treatment is replicated twice with two goats and were balanced for body weight. Each animal was allotted to an individual pen with a size of $1.2 \mathrm{x} 1 \mathrm{~m}$ with feeding and drinking troughs and the pens were well disinfected before the arrival of the goats. Feeding of the goats was done twice in a day at 7.00am and $4.00 \mathrm{pm}$ with forages during acclimatization period and later changed to the test diets which were given for 3 months. The animals were weighed weekly throughout the period of the feeding trial.

\section{Chemical analysis of diets}

Feed (Diets) were oven dried at $100^{\circ} \mathrm{C}$ for five hours cooled and weighed, the difference initial weight and final weight were taken as the moisture content in the diets. The percentage dry matter content was obtained as the difference between 100 and percentage moisture content and the proximate composition of diet samples were determined using the procedures of AOAC (2005), while the fractional parts of the diets were determined using the method of Van Soest et al, 1991.

\section{Slaughtering of animals}

At the end of three months feeding trial three bucks were randomly selected from each test diets and slaughtered following the procedures of Okubanjo (1997). The animals were demobilized by stunning, sticked, bled and the weights of the bled carcasses were recorded before eviscerating the carcasses. Thereafter, clean carcass weight, carcass length, chilled carcass weight as well as the external and internal offals weights were taken before the carcasses were fabricated, mills primal cuts according to Attah (1997) and Apata (2011).

\section{Meat characteristics}

Meat Samples were excised from the tight muscle of the carcasses from each treatment which were used to measure physical variables which included cooking loss, water holding capacity, cold loss, shortening and thermal shortening following the procedures of Honikel, (1998) and Apata (2011), the proximate composition of meat samples was determined according to AOAC (2000), while the sensory characteristics of meat samples were evaluated following the procedures of AMSA (2012) and (2015) using the taste panel method. Ten taste panellists were used and data were determined with a 9-point hedonic scale on which $1=$ dislike completely and $9=$ like completely.

\section{Statistical analysis}

The data generated from carcass and meat analyses were subjected to analysis of variance (ANOVA) using Statistical Analysis System (SAS 2002) while significantly different means were separated with the Duncan's multiple range test of the same software.

\section{Results and discussion}

Presented in Table 1 is the percentage ingredient composition of the experimental diet. Treatments 1 and 4 had Polyenzyme Maxigrain ${ }^{\circledR}$ added to them while the enzyme was included into treatments 2 and 3 at the rate of $0.13 \%$, respectively. 
Effects of utilizing treated and untreated corncobs and cassava peel-based diets

Table 1: Percentage ingredients composition of experimental diets

\begin{tabular}{lllll}
\hline \multicolumn{5}{c}{ Treatments } \\
Ingredients & T1 & $\begin{array}{l}\text { T2 } \\
\text { (UCP) }\end{array}$ & $\begin{array}{l}\text { T3 } 3 \\
(\mathrm{TCB})\end{array}$ & $\begin{array}{l}\text { T4 } \\
(\mathrm{TCP})\end{array}$ \\
\hline Cassava peels & 50.00 & - & 49.58 & - \\
Corncobs & - & 50.00 & - & 49.88 \\
GDS & 25.00 & 25.00 & 25.00 & 25.00 \\
BDG & 15.00 & 15.00 & 15.00 & 15.00 \\
Wheat offals & 6.00 & 6.00 & 6.00 & 6.00 \\
Molasses & 2.00 & 2.00 & 2.00 & 2.00 \\
Oyster shell & 1.00 & 1.00 & 1.00 & 1.00 \\
Salt & 1.00 & 1.00 & 1.00 & 1.00 \\
Polyenzyme (Maxigrain $®)$ & - & 0.13 & 0.13 & - \\
Total & 100.00 & 100.00 & 100.00 & 100.00 \\
\hline UCP - Untreated Cassava Peels, TCB $=$ Treated Corncobs, TCP $=$ Treated Cassava Peels, UCB = Untreated \\
Corncobs, GDS = Gliricidia septum, BDG = Brewer's Dried Grains
\end{tabular}

The chemical composition of experimental diets is highlighted in Table 2. The dry matter was significantly $(\mathrm{p}<0.05)$ higher in $\mathrm{T} 1$ and lower and the same in T2, T3 and T4, while Carbohydrate was higher $(\mathrm{p}<0.05)$ across $\mathrm{T} 2$ to $\mathrm{T} 4$ and lower in $\mathrm{T} 1$. The Neutral Detergent Fibre (NDF) was higher $(p<0.05)$ in T2 and lower in T1, but Acid detergent fibre was higher and the same in T2 and T4 respectively, while Acid detergent lignum was higher $(\mathrm{p}<0.05)$ in T2 and lower in $\mathrm{T} 1$ another chemical content of the diets showed no significant differences. In Table 3, carcass characteristics are presented. There was significant $(p<0.05)$ difference in the fasted weight of the slaughtered animals with animals in treatment 3 having higher weights followed by animals in T2 and those in T3 had the least weight, while bled weight was higher in carcasses in T1 and lower in those of T2; but clean carcass weight was higher in those carcasses of T3, followed by those of T2 and least in those of T4. The dressing percentage carcass length, and chilled carcass weight were significantly $(\mathrm{p}<0.05)$ higher in carcasses of T3 and lower in those of $\mathrm{T} 1$ and $\mathrm{T} 4$ respectively, however, both the chilling and percentage chilling loss was higher in T4 and least $(\mathrm{p}<0.05)$ in T3. In Treatments T2 and T3 adequate bleeding of the carcass was observed which could have been responsible for lower bled carcass weights, while T1 and T4 might have retained substantial blood especially in the vital organs (David et al. 2013) in this study it could be as a result of the enzyme included in the diets in Treatments 2 and 3. The same situation was observed in the chilled carcass weight, chilling loss and percentage chilling loss, the values for these variables were very low in treatments T2 and $\mathrm{T} 3$ compared with the values obtained for $\mathrm{T} 1$ and $\mathrm{T} 4$.

The results of external and internal offals of WAD goats were presented in T4 and all the offals both external and internal, were higher $(\mathrm{p}<0.05)$ in carcass of T3 followed by $\mathrm{T} 2$, while $\mathrm{T} 4$ had the least $(\mathrm{p}<0.05)$ values. This could be directly connected with the live weight of the carcasses in treatment T2 and T3 as a result of enzyme inclusion in the diets. Previously, Apata and Oke (2012) reported that carcass offals of broiler chickens showed significantly higher weights due to inclusion of enzyme in the diets, similar observations were made in this study that involved small ruminants the West African dwarf goats. 


\section{Apata, Eniolorunda, Olugbemi and Adedeji}

Table 2: Chemical composition of experimental diets (\%)

\begin{tabular}{|c|c|c|c|c|c|c|}
\hline \multirow[b]{2}{*}{ Variable } & \multicolumn{5}{|c|}{ Treatments } & \\
\hline & $\begin{array}{l}\text { T1 } \\
\text { (UCP) }\end{array}$ & $\begin{array}{l}\mathrm{T} 2 \\
(\mathrm{TCB})\end{array}$ & $\begin{array}{l}\text { T3 } \\
\text { (TCP) }\end{array}$ & $\begin{array}{l}\mathrm{T} 4 \\
\text { (UCB) }\end{array}$ & SEM & \\
\hline Moisture & 11.78 & 13.26 & 12.76 & 12.76 & 0.27 & \\
\hline Dry Matter & $88.25^{\mathrm{a}}$ & $86.74^{\mathrm{b}}$ & $87.24^{\mathrm{b}}$ & $87.22^{\mathrm{b}}$ & 0.28 & \\
\hline Ether Extract & 2.97 & 2.59 & 2.69 & 2.84 & 0.07 & \\
\hline Ash & 2.17 & 1.98 & 2.05 & 2.08 & 0.04 & \\
\hline Crude Fibre & 5.70 & 4.78 & 4.80 & 5.14 & 0.10 & \\
\hline Crude Protein & .87 & 11.02 & 11.57 & 11.40 & 0.32 & \\
\hline $\mathrm{CHO}$ & $64.83^{\mathrm{b}}$ & $66.38^{\mathrm{a}}$ & $65.93^{\mathrm{a}}$ & $66.20^{\mathrm{a}}$ & 0.27 & \\
\hline $\mathrm{OM}$ & 7.23 & 6.81 & 7.15 & 6.83 & 0.11 & \\
\hline NDF & $47.42^{\mathrm{d}}$ & $78.54^{\mathrm{a}}$ & $75.70^{\mathrm{b}}$ & $73.11^{\mathrm{c}}$ & 1.15 & \\
\hline $\mathrm{ADF}$ & $48.45^{b}$ & $50.74^{\mathrm{a}}$ & $49.13^{\mathrm{b}}$ & $50.13^{\mathrm{a}}$ & 0.75 & \\
\hline $\mathrm{ADL}$ & $15.89^{d}$ & $21.47^{\mathrm{a}}$ & $18.09^{\mathrm{c}}$ & $20.35^{\mathrm{b}}$ & 0.89 & \\
\hline Energy (kcal/kg) & 17.49 & 17.30 & 17.39 & 16.69 & 0.15 & \\
\hline \multicolumn{7}{|c|}{$\begin{array}{l}\text { UCP }- \text { Untreated Cassava Peels, } \mathrm{TCB}=\text { Treated Corncobs, } \mathrm{TCP}=\text { Treated Cassava Peels, } \mathrm{UCB}=\text { Untreated } \\
\text { Corncobs, } \mathrm{CHO}=\mathrm{Carbohydrate}, \mathrm{OM}=\text { Organic Matter, NDF }=\text { Neutral Detergent Fibre, } \mathrm{ADF}=\text { Acid } \\
\text { Detergent Fibre, } \mathrm{ADL}=\text { Acid Detergent Lignin }\end{array}$} \\
\hline \multicolumn{7}{|c|}{ Treatments } \\
\hline Variable & $\begin{array}{l}\mathrm{T} 1 \\
\text { (U }\end{array}$ & & $\begin{array}{l}\mathrm{T} 2 \\
(\mathrm{TCB})\end{array}$ & $\begin{array}{l}\text { T3 } \\
\text { (TCP) }\end{array}$ & $\begin{array}{l}\text { T4 } \\
\text { (UCB) }\end{array}$ & SEM \\
\hline Fasted Wt.(g) & & & $5,450.00^{b}$ & $5,500.00^{\mathrm{a}}$ & $5,230.00^{\mathrm{d}}$ & 0.68 \\
\hline Bled Carcass Wt.(g) & & & $4,850.00^{\mathrm{d}}$ & $4,861.00^{\mathrm{c}}$ & $4,899.00^{\mathrm{b}}$ & 0.18 \\
\hline Clean Carcass Wt.(g) & & & $2,250.00^{\mathrm{b}}$ & $2,350.00^{\mathrm{a}}$ & $1,250.00^{\mathrm{d}}$ & 0.38 \\
\hline Dressing $(\%)$ & 24 & & $41.28^{\mathrm{b}}$ & $42.72^{\mathrm{a}}$ & $23.63^{\mathrm{c}}$ & 4.45 \\
\hline Carcass Length $(\mathrm{cm})$ & & & $36.00^{\mathrm{b}}$ & $38.00^{\mathrm{a}}$ & $32.67^{\mathrm{d}}$ & 4.34 \\
\hline Chilled Carcass wt.(g) & & & $2,247.00^{\mathrm{b}}$ & $2,349.00^{\mathrm{a}}$ & $1,242.00^{\mathrm{d}}$ & 0.37 \\
\hline${\text { Chilling } \operatorname{Loss}_{(\mathrm{g})}}$ & 5.0 & & $3.00^{\mathrm{c}}$ & $1.00^{\mathrm{d}}$ & $8.00^{\mathrm{a}}$ & 8.86 \\
\hline Percentage Chilling Loss (\%) & 0.3 & & $0.13^{\mathrm{c}}$ & $0.04^{\mathrm{d}}$ & $0.64^{\mathrm{a}}$ & 10.20 \\
\hline
\end{tabular}

Means on the same row with different superscripts are statistically significant $(p<0.05)$; UCP - Untreated Cassava Peels, $\mathrm{TCB}=$ Treated Corncobs, $\mathrm{TCP}=$ Treated Cassava Peels, UCB $=$ Untreated Corncobs

Table 4: External and internal offals of WAD Goats fed experimental di ets

\begin{tabular}{|c|c|c|c|c|c|}
\hline \multicolumn{6}{|c|}{ Treatments } \\
\hline Variable & $\begin{array}{l}\mathrm{T} 1 \\
\text { (UCP) }\end{array}$ & $\begin{array}{l}\mathrm{T} 2 \\
(\mathrm{TCB})\end{array}$ & $\begin{array}{l}\text { T3 } \\
\text { (TCP) }\end{array}$ & $\begin{array}{l}\text { T4 } \\
\text { (UCB) }\end{array}$ & SEM \\
\hline \multicolumn{6}{|l|}{ External Offals } \\
\hline Head(g) & $35.50^{\mathrm{c}}$ & $60.00^{\mathrm{b}}$ & $65.00^{\mathrm{a}}$ & $32.00^{\mathrm{d}}$ & 7.80 \\
\hline $\operatorname{Neck}(g)$ & $10.00^{\mathrm{c}}$ & $15.00^{\mathrm{b}}$ & $18.50^{\mathrm{a}}$ & $7.30^{\mathrm{d}}$ & 2.51 \\
\hline Feet $(\mathrm{g})$ & $17.50^{\mathrm{c}}$ & $25.00^{\mathrm{b}}$ & $29.00^{\mathrm{a}}$ & $15.00^{\mathrm{d}}$ & 3.25 \\
\hline Skin(g) & $2.30^{\mathrm{b}}$ & $4.00^{\mathrm{a}}$ & $4.50^{\mathrm{a}}$ & $2.50^{\mathrm{b}}$ & 0.52 \\
\hline Scrotum $(g)$ & $4.00^{\mathrm{b}}$ & $5.00^{\mathrm{a}}$ & $5.50^{\mathrm{a}}$ & $3.50^{\mathrm{b}}$ & 0.63 \\
\hline \multicolumn{6}{|l|}{ Internal Offals } \\
\hline Heart $(g)$ & $29.14^{\mathrm{c}}$ & $43.72^{\mathrm{a}}$ & $46.00^{\mathrm{a}}$ & $28.24^{\mathrm{d}}$ & 4.69 \\
\hline Liver(g) & $12.50^{\mathrm{c}}$ & $15.30^{\mathrm{b}}$ & $17.50^{\mathrm{a}}$ & $10.00^{\mathrm{d}}$ & 2.54 \\
\hline Lungs $(g)$ & $9.12^{\mathrm{c}}$ & $10.62^{\mathrm{b}}$ & $12.24^{\mathrm{a}}$ & $7.00^{\mathrm{d}}$ & 1.11 \\
\hline Kidney(g) & $22.07^{\mathrm{c}}$ & $25.38^{\mathrm{b}}$ & $28.24^{\mathrm{a}}$ & $20.16^{\mathrm{d}}$ & 3.97 \\
\hline Full GIT(g) & $47.77^{\mathrm{c}}$ & $60.00^{\mathrm{b}}$ & $65.00^{\mathrm{a}}$ & $40.00^{\mathrm{d}}$ & 5.70 \\
\hline Empty GIT(g) & $95.00^{\mathrm{c}}$ & $195.00^{\mathrm{b}}$ & $220.00^{\mathrm{a}}$ & $87.50^{\mathrm{d}}$ & 46.11 \\
\hline
\end{tabular}




\section{Effects of utilizing treated and untreated corncobs and cassava peel-based diets}

The results of physical properties of meats from WAD goats' carcasses were shown in Table 5. The percentage cooking, cold losses, thermal and cold shortenings were significantly $(\mathrm{p}<0.05)$ higher in meat from carcasses in $\mathrm{T} 4$ by $\mathrm{T} 1$ and least in $\mathrm{T} 3$ and T2, while the cooking yield and Water Holding Capacity (WHC) were higher $(\mathrm{p}<0.05)$ in both $\mathrm{T} 3$ and $\mathrm{T} 2$ and lower in $\mathrm{T} 1$ and T4 respectively. Similar results were recorded by Eniolorunda et al. (2010), there were increase in cooking yield and WHC of meat from Yankasa rams fed graded levels of biscuit waste which contain a high level of amino acids (Protein); therefore, the inclusion of enzyme in diets $\mathrm{T} 2$ and $\mathrm{T} 3$ would have influenced the increase in the cooking yield and WHC and increase of cooking, cold losses as well as the thermal and cold shortenings observed in this study.

Table 5: Physical Properties of meat from WAD goats fed experimental diets

\begin{tabular}{llllll}
\hline & \multicolumn{5}{c}{ Treatments } \\
Variable & T1 & T2 & T3 & T4 & \\
\hline Cooking loss (\%) & $(\mathrm{UCP})$ & $(\mathrm{TCB})$ & $(\mathrm{TCP})$ & $(\mathrm{UCB})$ & SEM \\
Cooking yield (\%) & $15.00^{\mathrm{b}}$ & $14.80^{\mathrm{c}}$ & $12.45^{\mathrm{d}}$ & $16.25^{\mathrm{a}}$ & 2.31 \\
Thermal Shortening (\%) & $85.00^{\mathrm{c}}$ & $85.20^{\mathrm{b}}$ & $87.55^{\mathrm{a}}$ & $83.75^{\mathrm{d}}$ & 1.20 \\
Cold Loss (\%) & $13.67^{\mathrm{b}}$ & $12.50^{\mathrm{c}}$ & $11.30^{\mathrm{d}}$ & $16.27^{\mathrm{a}}$ & 3.97 \\
Cold Shortening (\%) & $13.40^{\mathrm{b}}$ & $11.66^{\mathrm{c}}$ & $10.60^{\mathrm{d}}$ & $17.05^{\mathrm{a}}$ & 2.39 \\
WHC (\%) & $17.34^{\mathrm{b}}$ & $13.67^{\mathrm{c}}$ & $11.37^{\mathrm{d}}$ & $18.50^{\mathrm{a}}$ & 4.05 \\
\hline
\end{tabular}

Means on the same row with different superscripts are statistically significant $(\mathrm{p}<0.05)$; UCP - Untreated Cassava Peels, TCB $=$ Treated Corncobs, TCP $=$ Treated Cassava Peels, UCB $=$ Untreated Corncobs WHC $=$ Water Holding Capacity

Table 6 highlighted the results of the proximate composition of meat from WAD goats fed treated and untreated corncobs and cassava peels. Both moisture and protein were significantly $(\mathrm{p}<0.05)$ higher in $\mathrm{T} 3$ followed by $\mathrm{T} 2$ as well as ether extract which were higher and the same in $\mathrm{T} 2$ and $\mathrm{T} 3$ and were lower in T4, however, ash content was higher in $\mathrm{T} 1$ and $\mathrm{T} 4$, but lower in $\mathrm{T} 2$ and $\mathrm{T} 3$. These results agreed with the report of Eniolorunda et al. (2010) except the result of the ash content which differed probably because corncobs and cassava peels are more fibrous than biscuit waste hence the increase in their ash content.

Table 6: Proximate Composition of meat from WAD goats fed experimental diets

\begin{tabular}{llllll} 
& \multicolumn{5}{c}{ Treatments } \\
Variable & T1 & T2 & T3 & T4 & \\
\hline Moisture (\%) & (UCP) & $($ TCB) & (TCP) & $($ UCB) & SEM \\
Crude Protein (\%) & $52.30^{\mathrm{c}}$ & $61.20^{\mathrm{b}}$ & $62.35^{\mathrm{a}}$ & $50.15^{\mathrm{d}}$ & 0.81 \\
Ether Extract (\%) & $17.22^{\mathrm{c}}$ & $18.35^{\mathrm{b}}$ & $19.40^{\mathrm{a}}$ & $16.13^{\mathrm{d}}$ & 0.12 \\
Ash (\%) & $4.27^{\mathrm{b}}$ & $5.30^{\mathrm{a}}$ & $5.52^{\mathrm{a}}$ & $3.20^{\mathrm{c}}$ & 0.07 \\
NFE (\%) & $5.21^{\mathrm{a}}$ & $3.60^{\mathrm{c}}$ & $4.83^{\mathrm{b}}$ & $5.70^{\mathrm{a}}$ & 0.02 \\
\hline
\end{tabular}

Means on the same row with different superscripts are statistically significant $(\mathrm{p}<0.05)$; UCP - Untreated Cassava Peels, TCB $=$ Treated Corncobs, TCP $=$ Treated Cassava Peels, UCB $=$ Untreated Corncobs, WHC = Water Holding Capacity, NFE $=$ Nitrogen Free Extract 


\section{Apata, Eniolorunda, Olugbemi and Adedeji}

The organoleptic profiles of WAD meat are shown in Table 7. All the sensorial variables were higher significantly $(\mathrm{p}<0.05)$ in $\mathrm{T} 3$ followed by $\mathrm{T} 2$ and least in T4. This could be due to the fact that the moisture content, WHC and protein were high in meat in treatments 3 and 2 thereby influenced the colour, flavour and juiciness of the meat which resulted in the increased acceptability of meat samples from T3 and $\mathrm{T} 2$ against those of $\mathrm{T} 1$ and $\mathrm{T} 4$ which was least accepted. The results obtained from this study on sensorial characteristics agreed with the findings of Apata et al. (2016) that meat acceptability increased with increase in colours protein, moisture and WHC which enhance flavour and juiciness and consumers' choice.

Table 7: Organoleptic profile of meat from WAD goats fed experimental diets

\begin{tabular}{llllll} 
& \multicolumn{5}{c}{ Treatments } \\
Variable & T1 & T2 & T3 & T4 & \\
\hline Colour & $(U C P)$ & $(T C B)$ & $(T C P)$ & $(U C B)$ & SEM \\
Flavour & $4.39^{\mathrm{c}}$ & $5.46^{\mathrm{b}}$ & $6.70^{\mathrm{a}}$ & $4.20^{\mathrm{c}}$ & 0.43 \\
Tenderness & $5.25^{\mathrm{c}}$ & $6.30^{\mathrm{b}}$ & $7.50^{\mathrm{a}}$ & $4.00^{\mathrm{d}}$ & 0.57 \\
Juiciness & $4.45^{\mathrm{c}}$ & $5.50^{\mathrm{b}}$ & $6.80^{\mathrm{a}}$ & $3.80^{\mathrm{c}}$ & 0.45 \\
Texture & $5.41^{\mathrm{c}}$ & $6.45^{\mathrm{b}}$ & $7.53^{\mathrm{a}}$ & $4.30^{\mathrm{d}}$ & 0.36 \\
OA & $4.37^{\mathrm{c}}$ & $5.55^{\mathrm{b}}$ & $6.75^{\mathrm{a}}$ & $4.25^{\mathrm{c}}$ & 0.53 \\
\hline
\end{tabular}

Means on the same row with different superscripts are statistically significant $(\mathrm{p}<0.05)$; UCP - Untreated Cassava Peels, $\mathrm{TCB}=$ Treated Corncobs, $\mathrm{TCP}=$ Treated Cassava Peels, $\mathrm{UCB}=$ Untreated Corncobs, WHC $=$ Water Holding Capacity, O A = Overall Acceptability

\section{Conclusion}

Based on this study, carcass and meat performances of WAD goats were better in enzyme supplemented dietary treatments than those of the untreated diets. Therefore, treatment 3 is recommended for feedlot farmers for improvement in carcass and meat performances in WAD goats.

\section{References}

Abdu, S. B., Hassan, M. R., Adamu, H. Y., Yashim, S. M. L. and Oketona, G. F. 2013. Nutritional Intake and digestibility of RedSokoto bucks fed varying levels of Ginelina (Ginelina orborea) leaf meal. Nig J. Anim. Sci. 15:125-133

Abores, S., Piannozzola, M. J., Soube, M. and Cerdeiras, M. P. 2006. Biodegradation of agricultural wastes by pleurotus species for its use as ruminants feed. Elect. J. Biotech. 9(3):15-19

Amaefule, F. O. and Ibeawuchi, J. A. 2005. Milk yield and composition of West African Dwarf (WAD) Does fed pigeon pea - cassava peel based diets. J. Anim. Vet. Adv. 4(12):991-999

AMSA 2012. Meat Colour Measurement Guidelines American Meat Science Association, Illinois, USA pp. 1923

AMSA 2015. Research Guidelines for Cookery, Sensory Evaluation and Instrumental Tenderness Measurements of Meat American Meat Science Association, Illinois, USA pp 23-75

AOAC 2000. Association of Official Analytical Chemists Washington, D.C. William Tryo Press Richmond Virginia, USA pp 214230

AOAC 2005. Official Methods of Analysis $18^{\text {th }}$ edition Association of Official Analytical Chemists, Washington, D.C; USA

Apata, E. S. and Oke, D. B. 2002. Performance and meat 


\section{Effects of utilizing treated and untreated corncobs and cassava peel-based diets}

characteristics of broiler chickens fed graded levels of dried poultry droppings meal supplemented with methionine and lysine Nig. Poultry Sci. J. 9:117-125

Apata, E. S., Akanji, A. M., Tijani, L. A. and Koleoso, I. M. 2006. Carcass and Meat assessment of broiler chickens fed raw benne seeds (sesamum indicum) basal diets with or without lysine supplementation. Assiut J. Agric. Sci. 47(6-2):546-554

Apata, E. S. 2011. Quality attributer of Red-Sokoto buck meat as influenced by post-slaughter processing methods. $\mathrm{Ph}$. D Thesis in the Department of Animal Science, University of Ibadan.

Attah, S. 1997. Live Performance, Carcass and Offal Characteristics of goats slaughtered at different weight. Ph.D. Thesis in the Department of Animal Science, University of Ibadan, Ibadan, Oyo State, Nigeria

Bolanle, K. S. Ahlhassan, S. 2012. Bioethanol Potentials of corncob hydrolysed using cellulose of Aspergiliusniger and Penicillium decumbens. Exci. J. 11:468-479

David, G. T., Dennis, N. M., Steven, M. L. and Parrish Jr, F. C. 2013. The Science of Animal Growth and Meat Technology. Meat Science Press, Ames, IOWA, USA pp 82-91

Eniolorunda, O. O., Apata, E. S., Badejo, B. B. and Okubanjo, A. O. 2010. Evaluation of the meat quality of Yankasa rams fed graded levels of biscuit waste Nig. J. Anim. Prod. 38(1):153-159

FAOSTAT, 2005. FAOSTAT Statistics Database Agricultural Production Statistics Rome, Italy FAO http://faostat.fao.org

FAOSTAT 2007. The United Nations Food and Agricultural Organization Meat goat breeds and breeding plans. Agricultural Research Services. United States Department of Agriculture.

Honikel, K. O. 1998. Reference methods for the assessment of physical characteristics of meat. Meat Sci. 49:447-457

Ikihimioya, I., Okoruwa, M. I. and Ikhatua, U. I. 2017. Nutrient intake and digestibility of West African Dwarf goats fed graded levels of Afzelia Africana and Newbouldea laevis as supplements to panicum maximum Nig. J. Anim. Prod. 44(4):297-306

Mattos, C. W., Carvalho, F. F. R., Dutra Junior, M. W., Veras, A. S. C., Batista, A. M. V., Alves, K. S., Ribeiro, V. L., Silva, M. J. S., Medeiros, G. R., Vasconcelos, R. M. J., Aranjo, A. O. and Miranda, S. B. 2006. Characteristica carcaca e dos compomentesnao - carcaca de cabritos moxoto e canindesubmetidos a doisniveis de alimentacao. Revista Brasileivade Zootecnica 35:2125-234

Okuban j o, A. O. 1997. Me at Characteristics of singed and conventionally dressed chevron carcasses J. Food Sci. Technol. 34(6):494-497

Onakomaiya, S. O., Oyesiku, K. A. and Jegede, S. J. 1992. Ogun State in Maps. Rex Charles Publication, Ibadan, Oyo State, Nigeria pp 7-8

SAS 2002. Statistical Analysis System. SAS Start Version 9, SAS Institute Inc. Garry, N.C, USA

Van Soest, P. J., Robertson, J. B. and Lewis, B. A. 1991. Methods of dietary fibre, neutral detergent fibre and non-starch polysaccharides in relation to animal nutrition. J. Dairy Sci. 74:3583-3597.

Received: $20^{\text {th }}$ May, 2020 Accepted: $25^{\text {th }}$ September, 2020 